\title{
Regulation of Calcineurin by Growth Cone Calcium Waves Controls Neurite Extension
}

\author{
Nathan J. Lautermilch and Nicholas C. Spitzer \\ Department of Biology and Center for Molecular Genetics, University of California, San Diego, La Jolla, \\ California 92093-0357
}

Growth cones generate spontaneous transient elevations of intracellular $\mathrm{Ca}^{2+}$ that regulate the rate of neurite outgrowth. Here we report that these $\mathrm{Ca}^{2+}$ waves inhibit neurite extension via the $\mathrm{Ca}^{2+}$-dependent phosphatase calcineurin $(\mathrm{CN})$ in $\mathrm{Xe}$ nopus spinal neurons. Pharmacological blockers of CN (cyclosporin $A$ and deltamethrin) and peptide inhibitors of $C N$ [the Xenopus CN (xCN) autoinhibitory domain and African swine fever virus protein $\mathrm{A} 238 \mathrm{~L}]$ block the $\mathrm{Ca}^{2+}$-dependent reduction of neurite outgrowth in cultured neurons. Time-lapse microscopy of growing neurites demonstrates directly that the reduction in the rate of outgrowth by $\mathrm{Ca}^{2+}$ transients is blocked by cyclosporin A. In contrast, expression of a constitutively active form of $x C N$ in the absence of waves results in shorter neurite lengths similar to those seen in the presence of waves. The developmental expression pattern of $\mathrm{xCN}$ transcripts in vivo coincides temporally with axonal pathfinding by spinal neurons, supporting a role of $\mathrm{CN}$ in regulating $\mathrm{Ca}^{2+}$-dependent neurite extension in the spinal cord. $\mathrm{Ca}^{2+}$ wave frequency and $\mathrm{Ca}^{2+}$ dependent expression of GABA are not affected by inhibition or activation of CN. However, phosphorylation of the cytoskeletal element GAP-43, which promotes actin polymerization, is reduced by $\mathrm{Ca}^{2+}$ waves and enhanced by suppression of $\mathrm{CN}$ activity. CN ultimately acts on the growth cone actin cytoskeleton, because disrupting actin microfilaments with cytochalasin $\mathrm{D}$ or stabilizing them with jasplakinolide negates the effects of suppressing or activating CN. Destabilization or stabilization of microtubules with colcemide or taxol results in $\mathrm{Ca}^{2+}$ independent inhibition of neurite outgrowth. The results identify components of the cascade by which $\mathrm{Ca}^{2+}$ waves act to regulate neurite extension.

Key words: axonal outgrowth; calcium transients; actin; microtubules; GAP-43; PP1; PP2A; PP2B
$\mathrm{Ca}^{2+}$ transients encode information across a range of frequencies (Berridge and Rapp, 1979; Tsien and Tsien, 1990; Meyer and Stryer, 1991; Spitzer and Sejnowski, 1997) and direct distinct aspects of differentiation in spinal neurons (Gu et al., 1994; Gu and Spitzer, 1995; Gomez and Spitzer, 1999). Growth cone $\mathrm{Ca}^{2+}$ waves regulate the rate of axon extension, which is inversely proportional to their frequency. The effects of $\mathrm{Ca}^{2+}$ transients on growth cone motility have been extensively studied (Haydon et al., 1984; Cohan and Kater, 1986; Mattson et al., 1988; Fields et al., 1990; Gomez et al., 1995), but the basis of decoding $\mathrm{Ca}^{2+}$ transients on this slow time scale, over periods of hours rather than seconds, has remained elusive. $\mathrm{Ca}^{2+}$-calmodulin kinase II (CamKII) has been implicated as a frequency decoder of $\mathrm{Ca}^{2+}$ transients (Deisseroth et al., 1995, 1998; De Koninck and Schulman, 1998). However, neurite outgrowth of spinal neurons is not affected by inhibitors of CamKII (Zheng et al., 1994) or of $\mathrm{Ca}^{2+}$-dependent protein kinase (PKC) (Gu and Spitzer, 1995), implying that another $\mathrm{Ca}^{2+}$-dependent enzyme is involved.

Calcineurin $(\mathrm{CN})$ is a $\mathrm{Ca}^{2+}$ - and calmodulin-dependent pro-

\footnotetext{
Received June 29, 1999; revised Oct. 14, 1999; accepted Oct. 15, 1999.

This work was supported by the National Institute of Neurological Disorders and Stroke Grant NS15918 and the National Institutes of Health Grant 5T32GN08107. We thank Steve Watt, Clay McDaniels, and Bill Conroy for valuable technical assistance, Stephen O'Keefe for providing the murine calcineurin B clone, Linda Dixon for providing the viral A238L clone, Karina Meiri for the rat GAP-43 construct and anti-GAP-43 antibodies, and Tim Gomez and Ray Smith for their comments on this manuscript.

The GenBank accession number for the Xenopus calcineurin A gene is AF019569. Correspondence should be addressed to Dr. Nathan J. Lautermilch, Department of Biology 0357, University of California, San Diego, 9500 Gilman Drive, La Jolla, CA 92093-0357. E-mail: nathan@biomail.ucsd.edu.

Copyright (C) 1999 Society for Neuroscience 0270-6474/99/200315-11\$15.00/0
}

tein phosphatase that has been reported to either stimulate or inhibit neurite outgrowth depending on cell type (Ferreira et al., 1993; Lyons et al., 1994; Chang et al., 1995). Local inactivation of $\mathrm{CN}$ causes temporary filopodial retraction in the growth cones of cultured neurons (Chang et al., 1995). Moreover, growth cones severed from their axons retain the ability to modulate filopodia in response to $\mathrm{Ca}^{2+}$ elevations (Rehder and Cheng, 1998), suggesting that $\mathrm{CN}$ acts on the local cytoskeleton. It is unlikely that $\mathrm{CN}$ affects neurite extension over the short term by regulating transcription, because neuronal morphology appears normal when inhibitors of RNA synthesis are applied (Ribera and Spitzer, 1989).

We investigated the role of $\mathrm{CN}$ in $\mathrm{Ca}^{2+}$-dependent regulation of axonal outgrowth in cultured Xenopus spinal neurons. Neurite extension increases when $\mathrm{CN}$ is suppressed pharmacologically in the presence of extracellular $\mathrm{Ca}^{2+}$ but not in its absence, implicating it in the transduction cascade. Accordingly we cloned Xenopus calcineurin $(\mathrm{xCN})$ to be able to manipulate its activity. Expression of the autoinhibitory domain of $\mathrm{xCN}$ in the presence of $\mathrm{Ca}^{2+}$ waves increases neurite extension, whereas expression of a constitutively active form of $\mathrm{xCN}$ in the absence of $\mathrm{Ca}^{2+}$ waves retards neurite growth. The frequency of $\mathrm{Ca}^{2+}$ waves is not affected by inhibiting or activating $\mathrm{CN}$, positioning the action of $\mathrm{CN}$ downstream of waves. Antibodies specific to phosphorylated GAP-43 reveal that $\mathrm{Ca}^{2+}$ waves act via $\mathrm{CN}$ to dephosphorylate GAP-43, consistent with the destabilization of actin filaments that slows neurite extension. The effects of suppressing or activating $\mathrm{CN}$ are blocked by destabilizing or stabilizing actin microfilaments but not microtubules, suggesting that $\mathrm{CN}$ acts on the growth cone actin cytoskeleton. The pattern of $\mathrm{xCN}$ expression in 
the developing spinal cord is temporally and spatially appropriate to be involved in the epigenetic mechanisms that regulate neurite outgrowth. Thus activation of $\mathrm{xCN}$ by spontaneous $\mathrm{Ca}^{2+}$ transients may control axon extension in vivo.

\section{MATERIALS AND METHODS}

Cell culture and expression of cRNA. Adult Xenopus laevis females were primed with human chorionic gonadotropin (United States Biochemicals, Cleveland, $\mathrm{OH}$ ), oocytes were fertilized in vitro, and embryos were allowed to develop to the neural plate stage (stage 15) (Nieuwkoop and Faber, 1967). For most experiments, including those involving application of pharmacological agents or expression of constructs, the presumptive spinal cord was isolated, disaggregated in a solution lacking divalent cations, and plated in a culture medium containing either 10 or $0 \mathrm{~mm}$ $\mathrm{Ca}^{2+}\left(116 \mathrm{~mm} \mathrm{NaCl}, 0.67 \mathrm{~mm} \mathrm{KCl}, 1.31 \mathrm{~mm} \mathrm{MgSO}_{4}\right.$, either $10 \mathrm{~mm} \mathrm{CaCl}_{2}$ or $0 \mathrm{mM} \mathrm{CaCl}_{2}$ with $1 \mathrm{~mm}$ EGTA, and $4.6 \mathrm{~mm}$ Tris; $\mathrm{pH}$ adjusted to 7.8 with $\mathrm{HCl}$ ) to promote or inhibit generation of spontaneous $\mathrm{Ca}^{2+}$ waves. For experiments involving expression of RNA constructs, fertilized oocytes were treated with $2 \%$ cysteine and $10 \%$ Holtfreter's solution, $\mathrm{pH} 8$, to remove the vitelline membrane. Injections of $10-20 \mathrm{ng}$ of cRNA into one cell of two-cell stage embryos were performed in a solution of $6 \%$ Ficoll in 10\% MMR (100 mM NaCl, $2 \mathrm{~mm} \mathrm{KCl,} 1 \mathrm{~mm} \mathrm{MgSO}$, $5 \mathrm{~mm}$ HEPES, $0.1 \mathrm{~mm}$ EDTA, and $2 \mathrm{mM} \mathrm{CaCl}_{2} ; \mathrm{pH}$ adjusted to 7.8 with $\mathrm{NaOH}$ ). A fluorescent marker (FITC-, rhodamine-, or fura-2-dextran; Molecular Probes, Eugene, OR) was coinjected with the cRNA to allow rapid identification of cells expressing constructs; nonfluorescent cells provided an internal control. Neurons were allowed to develop, and assays were performed at 18 to $24 \mathrm{hr}$ after plating. The effects of pharmacological inhibitors on neurite length were scored by measuring the length of the longest neurite for the first 10 neurons encountered in experimental and in control cultures. The effects of a $\mathrm{CN}$ autoinhibitory peptide, viral A238L protein, and constitutively active (CA)-xCN expression on neurite length were determined for the first 10 fluorescent and 10 nonfluorescent neurons in the same culture. For experiments involving measurements of neurite growth rate in response to $\mathrm{Ca}^{2+}$ transients generated by photorelease of caged $\mathrm{Ca}^{2+}$, neurons were grown on a laminin substrate to promote more rapid extension. Laminin $(25 \mu \mathrm{g} / \mathrm{ml}$; Sigma, St. Louis, MO) was coated onto acid-washed glass coverslips for $6 \mathrm{hr}$ at room temperature $\left(20^{\circ} \mathrm{C}\right)$ and washed with sterile PBS, pH 7.4. Neural explants (stage 21) were dissected in the presence of collagenase B $(0.15 \mathrm{mg} / \mathrm{ml}$; Boehringer Mannheim, Indianapolis, IN), washed, and plated in culture medium containing $100 \mathrm{~mm} \mathrm{NaCl}, 2 \mathrm{~mm} \mathrm{KCl}, 2 \mathrm{~mm}$ $\mathrm{CaCl}_{2}, 1 \mathrm{~mm} \mathrm{MgCl}_{2}$, and $5 \mathrm{~mm}$ HEPES, $\mathrm{pH}$ 7.6. Data are presented as mean \pm SEM, using a double-blind assignment; $n \geq 100$ neurons from three or more culture dishes unless otherwise indicated. Values are considered significantly different when $p<0.01$ unless denoted otherwise.

Pharmacological studies. Cyclosporin A (CsA), deltamethrin (DM), okadaic acid (OA), rapamycin (Rap), and tautomycin (Taut) were obtained from Calbiochem (San Diego, CA). Colcemide, cytochlasin D (Cyto D), jasplakinolide (Jasp), and taxol were from Molecular Probes. All drugs were stored at $-20^{\circ} \mathrm{C}$ in the dark. CsA and DM were made fresh for each experiment, dissolved in a cocktail of $50 \%$ ethanol and $50 \%$ DMSO, and then added to warmed $\left(37^{\circ} \mathrm{C}\right)$ culture medium and allowed to cool to room temperature. Colcemide, Cyto D, OA, Rap, Taut, and taxol were dissolved in DMSO, aliquoted for single use, and stored at $-20^{\circ} \mathrm{C}$ in the dark. Jasp was dissolved in methanol. CsA, DM, OA, Rap, and Taut were added $4 \mathrm{hr}$ after plating; colcemide, Cyto D, Jasp, and taxol were added $7 \mathrm{hr}$ after plating to allow neurite initiation. Final ethanol, methanol, and DMSO concentrations were $<0.001 \%$. Dose-response curves were determined for each agent to identify the minimum effective concentration.

Isolation of Xenopus calcineurin A. A partial clone of Xenopus CN A, 1068 bp in length, was isolated from a 1 month Xenopus tadpole brain cDNA library. Because the partial clone lacked the $5^{\prime}$ portion of the $\mathrm{CN}$ gene, it was isolated by $5^{\prime}$ rapid amplification of cDNA ends (RACE; Life Technologies, Gaithersburg, MD). A single gene-specific primer (gtcatggtaaccagagacttc) was used to generate a $1 \mathrm{~kb}$ fragment including $300 \mathrm{bp}$ of overlap with the original clone from stage 30 spinal cord mRNA. A second gene-specific nested primer (ggcctacaagtactgtaataag) was used in conjunction with a $5^{\prime}$-tailed primer for exponential amplification of the $5^{\prime}$ fragment. The $5^{\prime}$ fragment was isolated using the TA cloning kit (Invitrogen, San Diego, CA) and ligated to the partial clone at a unique Bst 1107 I site.
Inhibitory and constitutively active constructs. A PCR-based approach was used to generate constructs encoding two peptide inhibitors specific for $\mathrm{CN}$ and a constitutively active form of the enzyme. The large autoinhibitory domain of $\mathrm{CN}$ was isolated using primers (forward, aggcctaaaggtcttacacccaccg; reverse, tctagatcactgaatattgctgccg) based on the work of Sagoo et al. (1996), generating a $291 \mathrm{bp}$ product. The African swine fever virus protein A238L sequence (Miskin et al., 1998) (construct kindly provided by Dr. Linda Dixon) was isolated in a similar manner (forward, aggcctatggaacacatgtttcc; reverse, ctcgagcggccgccagtgtgatgg), generating a $704 \mathrm{bp}$ product. A similar approach was used to generate a CA construct that is $\mathrm{Ca}^{2+}$ and calmodulin independent $(\mathrm{CA}-\mathrm{xCN})$, with primer design based on previously published work (O'Keefe et al., 1992) to isolate the $1.2 \mathrm{~kb}$ catalytic region of $\mathrm{CN}$ (forward, gaattcaatgtccgagcacaagg; reverse, tctagatcactagtttctgataacttcc). All PCR products were subcloned into pCR2.1 (Invitrogen) and later subcloned into CS2+MYC with five consecutive myc tags (designed by Dr. David Turner). Each insert was sequenced to verify the integrity of the PCR product. mRNA was synthesized using the SP6 mMessage machine mRNA transcription kit (Ambion, Austin, TX) and injected into one cell of a two-cell stage Xenopus embryo along with a fluorescent marker. CA-xCN was coinjected with murine CN B cRNA (construct generously provided by Dr. Stephen O'Keefe) to enhance stability of the enzyme.

In situ hybridization. In situ hybridization of Xenopus embryos was performed as described previously (Harland, 1991; Ferreiro et al., 1992), with modifications (Burger and Ribera, 1996). Antisense and sense RNA probes were constructed containing $1 \mathrm{~kb}$ of the $3^{\prime}$ untranslated region and $400 \mathrm{bp}$ of the coding region. To facilitate visualization after staining, we used albino Xenopus embryos obtained from mated-pair fertilizations.

$\mathrm{Ca}^{2+}$ imaging. Relative levels of intracellular $\mathrm{Ca}^{2+}$ were measured using Fluo 3 AM or 4 AM (Molecular Probes). Cells were loaded with 5 $\mu \mathrm{M} \mathrm{Ca}^{2+}$ indicator or with $2.5 \mu \mathrm{M} \mathrm{Ca}^{2+}$ indicator and $2.5 \mu \mathrm{M}$ NP-EGTA AM (caged $\mathrm{Ca}^{2+}$ ) (in $0.02 \%$ pluronic acid and $0.2 \%$ DMSO) for $60 \mathrm{~min}$ and then perfused with culture medium. Individual cultures were imaged for not $>75 \mathrm{~min}$. Measurements of $\mathrm{Ca}^{2+}$ transients produced in response to photorelease of caged $\mathrm{Ca}^{2+}$ from NP-EGTA AM and determinations of consequent rates of neurite extension were performed with a Bio-Rad MRC600 confocal microscope (Hercules, CA). Images were acquired at $15 \mathrm{sec}$ intervals at $10-18 \mathrm{hr}$ in culture using a $100 \times$ objective. Neurite outgrowth was measured over 24 min intervals, after photorelease of caged $\mathrm{Ca}^{2+}$ at 8 and $16 \mathrm{~min}$; data were tabulated from neurons in which extension recovered after photorelease. Fluorescence pixel intensities were analyzed with NIH Image (W. Rasband, National Institutes of Health, Bethesda, MD), changes were normalized to baseline, and waves were scored as events $>150 \%$ of their baseline fluorescence $\left(F / F_{0}\right)$ that were distinguished from spikes by their kinetics ( $\mathrm{Gu}$ et al., 1994). Time-lapse measurements of spontaneous $\mathrm{Ca}^{2+}$ transients and identification of fluorescent cells for neurite length assays were accomplished with a TTE CCD camera mounted on a Zeiss IM-35 Photoscope. Images were captured at $10 \mathrm{sec}$ intervals at $12-24 \mathrm{hr}$ in culture using $20 \times$ or $40 \times$ water immersion objectives. Fluorescence pixel intensities were analyzed with the Metamorph program (Universal Imaging Corporation, West Chester, PA), and waves were scored as described above.

Immunocytochemistry. Analysis of myc immunoreactivity followed previously described protocols, with modifications (Spitzer et al., 1993; $\mathrm{Gu}$ and Spitzer, 1995). Cells were fixed with a solution of $4 \%$ paraformaldehyde and $0.1 \%$ glutaraldehyde, washed in PBS, and incubated with an anti-myc mouse monoclonal antibody (Santa Cruz Biotechnology, Santa Cruz, CA) at 1:1000 overnight at $4^{\circ} \mathrm{C}$. A secondary biotinylated goat anti-mouse antibody (Jackson ImmunoResearch, West Grove, PA) was used at 1:500 for $2 \mathrm{hr}$ at $20^{\circ} \mathrm{C}$. Avidin-conjugated horseradish peroxidase and diaminobenzidine or NovaRed substrate (Vector Laboratories, Burlingame, CA) were used to identify myc-positive neurons. GABA immunoreactivity was detected in an identical manner to myc, using a rabbit anti-GABA polyclonal primary antibody (Incstar, Stillwater, $\mathrm{MN}$ ) at 1:5000 and a tetramethylrhodamine isothiocyanatebiotinylated goat anti-rabbit secondary antibody (Jackson ImmunoResearch) at 1:500.

Immunoblot analysis. Neural plates from embryos injected with rat GAP-43 cRNA (construct generously provided by Dr. Karina Meiri) were cultured as described above and harvested 18-24 hr after plating; 15 or more cultures were pooled to allow detection of GAP-43. Protein was solubilized in SDS sample buffer containing 5\% $\beta$-mercaptoethanol, subjected to SDS-PAGE on $8 \%$ polyacrylamide gels, and electroblotted on nitrocellulose. Blots were blocked with $3 \%(\mathrm{w} / \mathrm{v})$ Carnation nonfat dry milk in PBS containing $0.1 \%$ Tween 20 , incubated overnight at $4^{\circ} \mathrm{C}$ 
with anti-GAP-43 mAb 2G12 (courtesy of Dr. Karina Meiri) at 1:10 in the same solution, washed in PBS containing $0.1 \%$ Tween 20 , and then incubated for $1 \mathrm{hr}$ at $20^{\circ} \mathrm{C}$ with horseradish peroxidase coupled to goat anti-mouse $\mathrm{IgG}$ (Jackson ImmunoResearch) to detect bound mAb. Signals were detected using enhanced chemiluminescence (Amersham, Arlington Heights, IL), digitized with a Color One scanner (Apple Computer, Cupertino, CA), and band intensities were quantitated using NIH Image software (W. Rasband, National Institutes of Health). Molecular mass markers for blots included phosphorylase B $(97.4 \mathrm{kDa})$, bovine serum albumin $(66.2 \mathrm{kDa})$, ovalbumin $(45 \mathrm{kDa})$, and carbonic anhydrase (31 kDa) (low range; Bio-Rad).

\section{RESULTS}

\section{Pharmacological inhibition of calcineurin enhances neurite outgrowth}

Growth cone $\mathrm{Ca}^{2+}$ waves are abolished and neurites are significantly longer when neurons are grown in the absence of external $\mathrm{Ca}^{2+}$ rather than in its presence, consistent with previous observations (Bixby and Spitzer, 1984; Gu et al., 1994; Gu and Spitzer, 1995). We investigated the regulation of neurite extension by the $\mathrm{Ca}^{2+}$-dependent protein phosphatase calcineurin (PP2B) by applying cyclosporin A (CsA; $10 \mathrm{~nm})$ and dellamethria (DM; $1 \mathrm{nM})$ to cultures in the absence or presence of $\mathrm{Ca}^{2+}$ to eliminate or enable spontaneous production of waves. CsA binds to cyclophilin A and inhibits CN indirectly (Liu et al., 1991), whereas DM apparently binds directly to CN (Enan and Matsumura, 1992). Inhibition of $\mathrm{CN}$ has no effect on neurite length in the absence of $\mathrm{Ca}^{2+}$ waves. However, in the presence of $\mathrm{Ca}^{2+}$ waves, inhibition of $\mathrm{CN}$ generates longer neurite lengths, resembling those observed in $0 \mathrm{Ca}^{2+}$ (Fig. $1 A ; p<0.01$ ). Higher concentrations of CsA (1 $\mu \mathrm{M})$ and DM (100 nM) inhibit neurite extension in a $\mathrm{Ca}^{2+}$-independent manner, consistent with previous observations (Chang et al., 1995), presumably by interfering with other cellular functions. Lower concentrations have no effect on neurite outgrowth. Immunophilins implicated in axonal outgrowth (Lyons et al., 1994; Chang et al., 1995; Gold, 1997; Snyder at al., 1998) do not appear to regulate $\mathrm{Ca}^{2+}$-dependent outgrowth because rapamycin (Rap), which binds immunophilins but does not inhibit $\mathrm{CN}$, has no effect on neurite length (control, $92 \pm 6$ $\mu \mathrm{m} ; 1 \mu \mathrm{M}$ Rap, $100 \pm 6 \mu \mathrm{m} ; n>30)$. Thus $\mathrm{CN}$ seems to be a necessary component in the signal transduction cascade by which $\mathrm{Ca}^{2+}$ waves control the rate of neurite extension in vitro.

Because $\mathrm{CN}$ can affect the activity of other serine-threonine phosphatases, we determined whether they regulate neurite extension in response to $\mathrm{Ca}^{2+}$ waves by testing inhibitors of the PP2A and PP1 families of protein phosphatases. Okadaic acid (OA) is a potent inhibitor of PP2A members at low concentrations and PP1 members at higher concentrations (for review, see MacKintosh and MacKintosh, 1994). The dose-response relationship for $\mathrm{OA}$ reveals that $\mathrm{PP} 2 \mathrm{~A}$ members promote neurite growth in the absence of $\mathrm{Ca}^{2+}$ waves rather than inhibit it in a $\mathrm{Ca}^{2+}$-dependent manner (Fig. $1 B$ ). At 300 pM, OA has no effect on neurite length, as expected, because this concentration is below the levels that inhibit phosphatase activity (Favre et al., 1997). Specific inhibition of PP2A family members (3 nM) results in neurite lengths that are reduced only in the absence of extracellular $\mathrm{Ca}^{2+}$. Increasing the $\mathrm{OA}$ concentration to $30 \mathrm{nM}$, which inhibits PP1 as well as PP2A family members, leads to no significant further reduction in neurite lengths. These results suggest that the activity of PP2A but not PP1 phosphatases stimulates neurite growth in the absence of $\mathrm{Ca}^{2+}$ waves; however neither family acts downstream of $\mathrm{Ca}^{2+}$ waves to inhibit neurite outgrowth. To identify the contribution of PP1 phosphatases we used Taut, which specifically inhibits this family at low concentrations
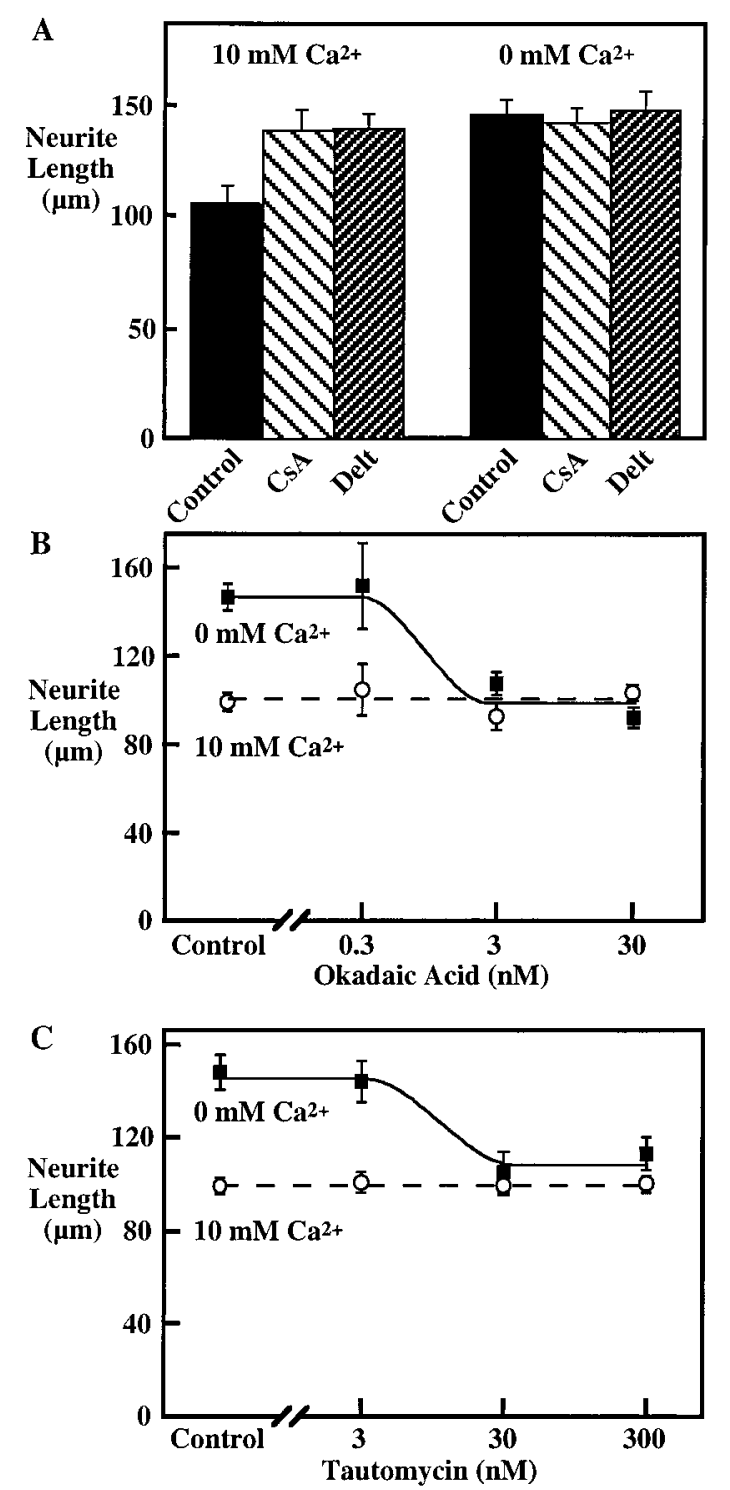

Figure 1. Pharmacological inhibition of $\mathrm{CN}$ but not other ser-thr phosphatases increases neurite lengths in the presence of $\mathrm{Ca}^{2+} . A$, Neurite lengths are significantly increased by $10 \mathrm{nM}$ CsA or $1 \mathrm{nM}$ DM (Delt) in the presence of $10 \mathrm{mM} \mathrm{Ca}^{2+}$. In the absence of extracellular $\mathrm{Ca}^{2+}$, inhibition of CN (PP2B) by $10 \mathrm{~nm} \mathrm{CsA}$ or $1 \mathrm{~nm} \mathrm{DM}$ has no effect on neurite lengths. Data are mean $\pm \operatorname{SEM}(n \geq 100)$. $B$, OA at $300 \mathrm{pM}$, a concentration that does not inhibit members of the PP1 or PP2A families of protein phosphatases, has no effect on neurite length $\pm \mathrm{Ca}^{2+}$. OA at $3 \mathrm{nM}$, which inhibits members of PP2A but not PP1, inhibits neurite lengths in the absence of $\mathrm{Ca}^{2+}$, suggesting that this family promotes neurite extension in the absence of waves. OA at $30 \mathrm{nM}$, which inhibits members of both PP2A and PP1, causes no further inhibition of neurite outgrowth. $C$, Taut at $3 \mathrm{nM}$, a concentration that affects only PP1 and not PP2A phosphatases, has no effect on neurite extension $\pm \mathrm{Ca}^{2+}$. Taut at 30 and $300 \mathrm{~nm}$, which inhibit members of both PP1 and PP2A, results in $\mathrm{Ca}^{2+}$-independent inhibition of neurite lengths. Data for $B$ and $C$ are mean $\pm \operatorname{SEM}(n \geq 30)$.

(MacKintosh and MacKintosh, 1994). At 3 nM, tautomycin (Taut) has no effect on neurite extension in the presence or absence of $\mathrm{Ca}^{2+}$ (Fig. 1C). Since CN inhibition can enhance PP1 activity by suppressing Inhibitor-1, a CN substrate that blocks PP1 when dephosphorylated, these data also make it unlikely that members of PP1 are responsible for the increase in neurite outgrowth in the absence of waves. In agreement with the effects of OA, higher 
Figure 2. Inhibition of calcineurin suppresses the slowing of neurite outgrowth by $\mathrm{Ca}^{2+}$ transients generated by photorelease of caged $\mathrm{Ca}^{2+}$. $A$, UV stimulation of a growth cone elicits a $\mathrm{Ca}^{2+}$ transient (right; laminin substrate) that mimics a spontaneous $\mathrm{Ca}^{2+}$ wave in a different growth cone (left ; tissue culture plastic substrate). $B$, Induced $\mathrm{Ca}^{2+}$ transients mimic spontaneous growth cone $\mathrm{Ca}^{2+}$ waves in both duration and amplitude (mean \pm SEM; $n=5$ ). $C$, Growth cone $\mathrm{Ca}^{2+}$ transients evoked at $8 \mathrm{~min}$ intervals (arrowheads) inhibit the rate of outgrowth. $D$, Inhibition of calcineurin (CsA, $10 \mathrm{~nm}$ ) negates the braking effect of $\mathrm{Ca}^{2+}$ transients (arrowheads) on neurite outgrowth. Neurons were imaged to establish a baseline rate of outgrowth, followed by photorelease of $\mathrm{Ca}^{2+}$ in the growth cone at $8 \mathrm{~min}$ intervals to mimic growth cone waves. $E$, Inhibition of neurite outgrowth by $\mathrm{Ca}^{2+}$ transients is suppressed in the presence of CsA (10 nM), suggesting that activation of calcineurin slows neurite outgrowth (mean \pm SEM; $n \geq 15 ; p>0.05)$. Con, Control; Spont, spontaneous.

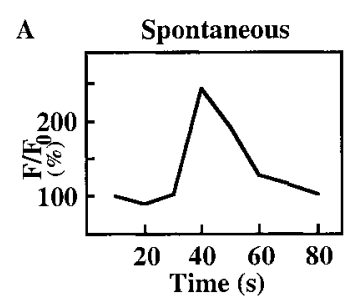

C
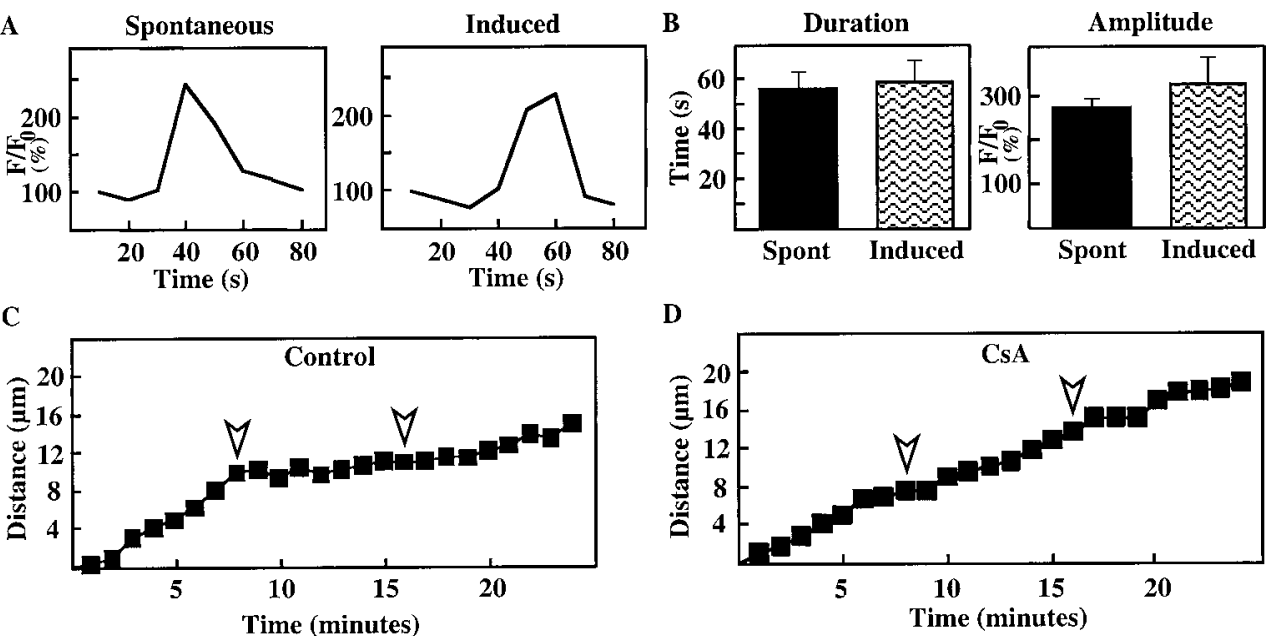

D

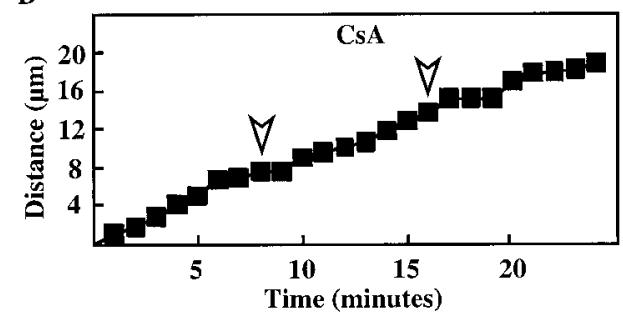

$\mathbf{E}$

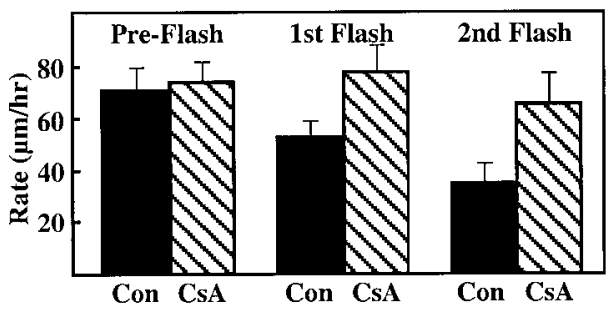

concentrations of tautomycin that inhibit members of the PP2A family (30 and $300 \mathrm{nM}$ ) suppress neurite lengths only in the absence of extracellular $\mathrm{Ca}^{2+}$. Thus, neither PP2A nor PP1 phosphatase families seem to have a role in the $\mathrm{Ca}^{2+}$-dependent inhibition of neurite extension in Xenopus spinal neurons.

\section{Regulation of neurite extension by $\mathrm{Ca}^{2+}$ transients is suppressed by CsA}

To test more directly whether $\mathrm{CN}$ slows neurite extension in response to $\mathrm{Ca}^{2+}$ transients, we simulated waves by focal photorelease of caged $\mathrm{Ca}^{2+}$ in the growth cone under conditions that permitted or suppressed $\mathrm{CN}$ activity. In preliminary experiments, photodynamic damage appeared to result from the stimulation of $\mathrm{Ca}^{2+}$ transients for the several hours necessary to detect changes in the relatively slow rate of neurite extension, when neurons were grown on uncoated culture dishes. Accordingly, we analyzed the more rapid neurite outgrowth achieved with neural tube explants grown on laminin. Laminin also suppresses spontaneous growth cone wave production, facilitating temporal control of $\mathrm{Ca}^{2+}$ elevations via photorelease. Cells were loaded with Fluo 3 AM and NP-EGTA AM (caged $\mathrm{Ca}^{2+}$ ), and baseline rates of growth were established for each neuron. Subsequently $\mathrm{Ca}^{2+}$ was uncaged with brief UV flashes delivered to the growth cone (Gomez and Spitzer, 1999). $\mathrm{Ca}^{2+}$ transients generated in this way mimic spontaneous $\mathrm{Ca}^{2+}$ waves in their amplitude and duration (Fig. 2A,B). Moreover, imposition of $\mathrm{Ca}^{2+}$ transients at a frequency of $8 / \mathrm{hr}$ ( $\mathrm{Gu}$ and Spitzer, 1992) slows the rate of neurite outgrowth. However in the presence of $10 \mathrm{~nm} \mathrm{CsA}$, the braking effect of $\mathrm{Ca}^{2+}$ waves on neurite outgrowth is significantly reduced (Fig. $2 C-E$ ). These data indicate that neurite outgrowth on a natural laminin substrate is regulated by $\mathrm{Ca}^{2+}$ transients, similar to growth on culture plastic and in vivo, and suggest that $\mathrm{Ca}^{2+}$ waves are linked to neurite extension via the activity of $\mathrm{CN}$.

\section{Cloning of Xenopus calcineurin}

Because $\mathrm{CN}$ emerged as an important link between $\mathrm{Ca}^{2+}$ waves and reduced neurite outgrowth, we cloned the $\mathrm{xCN}$ A subunit. A $1.1 \mathrm{~kb}$ partial clone was isolated from a Xenopus brain cDNA library. The remaining $5^{\prime}$ portion of the gene was isolated using RACE and ligated with the original gene fragment to produce a full-length clone. $\mathrm{xCN}$ corresponds to the neuronal $\mathrm{A}$ isoform and has the highest identity with human, rat, and mouse calcineurin at the amino acid level (94\%) based on BLASTx searches of GenBank (Altschul et al., 1997).

\section{Peptide inhibition of calcineurin enhances neurite extension}

To characterize further the effect of inhibition of endogenous $\mathrm{CN}$, we used specific blockers to examine the role of $\mathrm{CN}$ in the regulation of neurite outgrowth by $\mathrm{Ca}^{2+}$ waves. Because $\mathrm{xCN}$ contains an autoinhibitory domain that inhibits enzymatic activity, we used a PCR-based approach to isolate various sized domains encoding the inhibitory region. PCR products were subcloned into an expression vector encoding five consecutive myc tags at the 5' end of the sequence. cRNA was synthesized and coinjected into one cell of a two-cell stage embryo with a fluorescent lineage marker (rhodamine-dextran) that allows identification of living neurons containing the constructs; myc staining demonstrated $>90 \%$ correlation with fluorescently labeled cells, indicating that the constructs are expressed and that the proteins are stable over the time period examined. Injection of a construct encoding a myc-tagged 26 amino acid $\mathrm{CN}$ autoinhibitory peptide (Hubbard and Klee, 1989; Perrino et al., 1995) into one cell of two-cell stage embryos has no effect on neurite lengths in culture (data not shown).

In contrast, expression of a 97 amino acid fragment of the $\mathrm{C}$ terminal of $\mathrm{CN}$ (including the 26 amino acid autoinhibitory peptide), which has been shown to be eightfold more potent than 
A

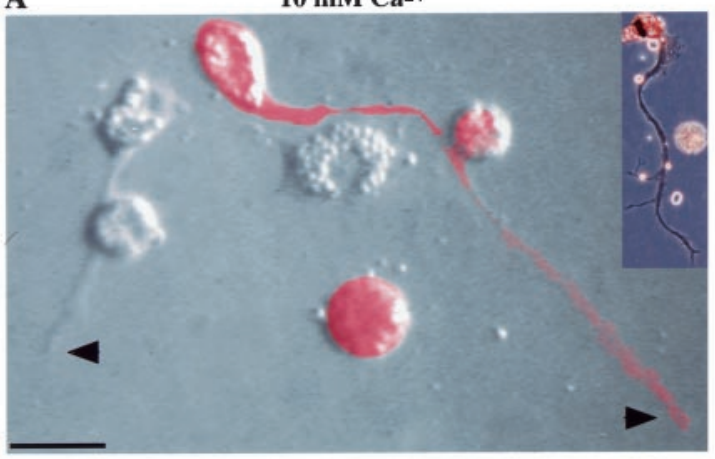

$10 \mathrm{mM} \mathrm{Ca}^{2+}$

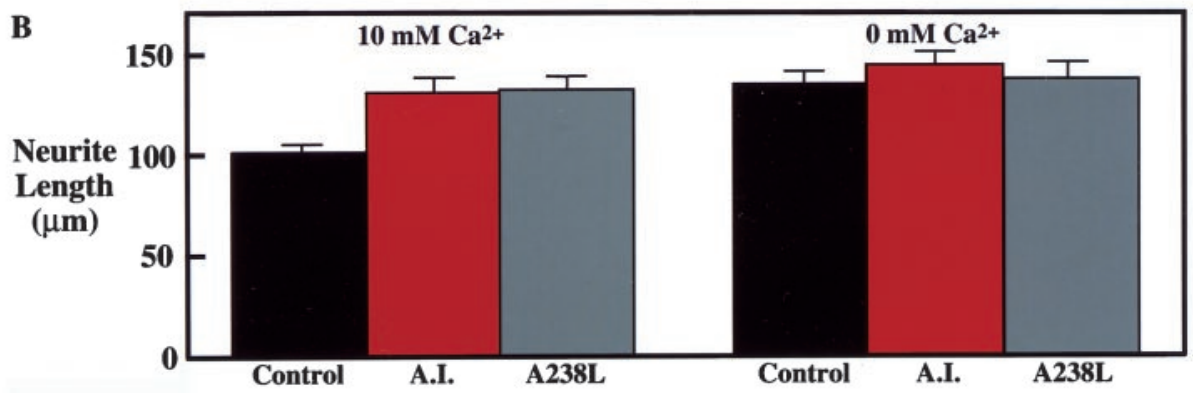

$0 \mathrm{mM} \mathrm{Ca}^{2+}$

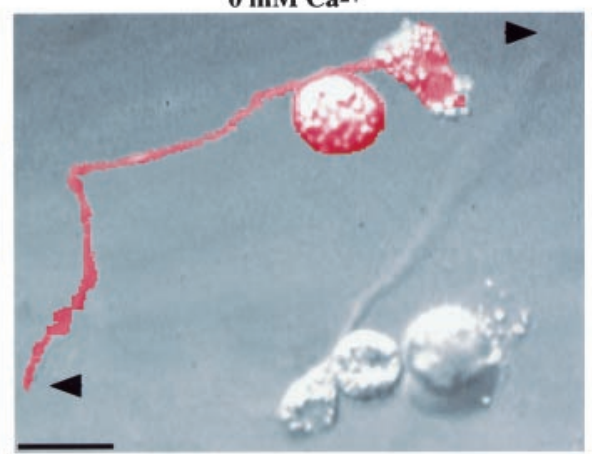

A.I.
A238L
Figure 3. Peptide inhibition of $\mathrm{CN}$ increases neurite lengths in the presence of $\mathrm{Ca}^{2+} . A$, Myc-tagged xCN autoinhibitory domain (A.I.) cRNA was coinjected into one cell of a two-cell stage embryo with a fluorescent lineage tracer (rhodamine-dextran) to identify A.I.-expressing cells. Nonfluorescent neurons serve as internal controls. $A r$ rowheads indicate growth cones. Inset shows a myc-labeled neuron, demonstrating stability of the construct at $1 \mathrm{~d}$ in culture, is shown. Neurons were grown $\pm \mathrm{Ca}^{2+}$. Scale bars, $25 \mu \mathrm{m}$. $B$, Neurite extension in the presence of external $\mathrm{Ca}^{2+}$ is significantly increased in cells expressing A.I. or the viral CN inhibitor A238L $(p<0.01)$. Neurons grown in the absence of $\mathrm{Ca}^{2+}$ and expressing A.I. or A238L have neurite lengths similar to those of controls. Data are mean \pm SEM $(n \geq 60)$. the shorter peptide in inhibiting enzyme activity (Sagoo et al., 1996), leads to neurons with greater neurite lengths when grown in the presence of $\mathrm{Ca}^{2+}$ (Fig. 3A). Injecting 5-10 ng cRNA had no effect on neurite length, whereas increasing the amount to 20-25 ng promoted neurite extension in the presence of $\mathrm{Ca}^{2+}$ to lengths not significantly different from those seen in the absence of $\mathrm{Ca}^{2+}(p<0.01)$. These results are consistent with the titration of endogenous $\mathrm{xCN}$, and suggest that the effect of the autoinhibitory peptide is specific. The increases in neurite length by expression of the autoinhibitory peptide, CsA or DM treatment, or the absence of $\mathrm{Ca}^{2+}$ are indistinguishable (Fig. $3 B ; p<0.01$ ). Moreover CsA treatment of neurons expressing effective concentrations of autoinhibitory peptide yielded neurite lengths that were not different from those obtained by treatment with either inhibitor alone. Confirmation of the results with the autoinhibitory peptide was provided by experiments using a construct encoding myc-tagged African swine fever virus protein A238L, which has no sequence similarity to the autoinhibitory peptide and blocks CN activity by a different mechanism (Miskin et al., 1998). Again neurite extension is more rapid in neurons cultured in the presence of $\mathrm{Ca}^{2+}$ and achieves lengths similar to those of neurons grown in the absence of $\mathrm{Ca}^{2+}$ (Fig. 3B). Expression of either construct has no effect on neurite lengths in the absence of $\mathrm{Ca}^{2+}$ waves. These results with two specific peptide inhibitors of $\mathrm{CN}$ activity, with the convergent effects of the pharmacological inhibitors, suggest that this enzyme is a necessary component of the signal transduction cascade by which $\mathrm{Ca}^{2+}$ regulates neurite outgrowth.

\section{Constitutively active calcineurin restricts neurite outgrowth}

To resolve whether $\mathrm{xCN}$ is sufficient to regulate neurite extension, a CA form of $\mathrm{xCN}$ was created to test for gain of function in the absence of extracellular $\mathrm{Ca}^{2+}$. Using an approach similar to that for construction of the autoinhibitory peptide, we generated a myc-tagged truncated form of $\mathrm{CN}$ containing the catalytic region of the enzyme but lacking the calmodulin-binding and autoinhibitory domains to produce a $\mathrm{Ca}^{2+}$-independent enzyme. CA-xCN A cRNA was coinjected into one cell of a two-cell stage embryo with murine CN B cRNA (O'Keefe et al., 1992) to enhance A subunit stability. The mouse CN B subunit is $100 \%$ identical to the rat, bovine, and human homologs at the amino acid level (C. E. Nargang, A. D. Bottorff, and K. Adachi, GenBank accession number GI180705, 1993) (Guerini et al., 1989; Ueki et al., 1992), implying that murine $\mathrm{CN} B$ is a sufficient substitute for Xenopus CN B. A fluorescent lineage marker (FITC-dextran) was coinjected with $\mathrm{CA}-\mathrm{xCN}$ A and murine $\mathrm{CN}$ $\mathrm{B}$ to identify expression in living neurons. Neurite extension is inhibited in the absence of external $\mathrm{Ca}^{2+}$ in neurons expressing the CA-xCN enzyme, yielding neurite lengths similar to those observed for neurons grown in the presence of $\mathrm{Ca}^{2+}$ and not expressing the construct (Fig. 4; $p<0.01$ ). Expression of $\mathrm{CN} \mathrm{B}$ alone or with an inactive form of $\mathrm{CA}-\mathrm{xCN}$ (linked to green fluorescent protein at the $\mathrm{C}$ terminal) is ineffective in restricting neurite lengths. Neurons expressing $\mathrm{CA}-\mathrm{xCN}$ and grown in the presence of $\mathrm{Ca}^{2+}$, enabling production of $\mathrm{Ca}^{2+}$ waves, have neurite lengths that are not different from controls (Fig. 4B). This result indicates that a constitutively active form of $\mathrm{CN}$ mimics the effect of $\mathrm{Ca}^{2+}$ waves. The effect of $\mathrm{CA}-\mathrm{xCN}$ is predicted to be inhibited by CsA (Clipstone et al., 1994) because it contains the site to which this agent binds. Indeed, addition of CsA to neurons expressing CA-xCN negates the inhibitory effect of $\mathrm{CA}-\mathrm{xCN}$ and increases neurite lengths to an extent not significantly different from that observed in the absence of $\mathrm{Ca}^{2+}(p<0.01)$. The reciprocal effects of $\mathrm{xCN}$ loss and gain of function in the presence and absence of $\mathrm{Ca}^{2+}$ waves suggest that this $\mathrm{Ca}^{2+}$-dependent enzyme is necessary and sufficient to regulate neurite extension in response to transient elevations of $\mathrm{Ca}^{2+}$.

\section{Developmental expression of Xenopus calcineurin}

To characterize the developmental appearance of $\mathrm{xCN}$, we performed whole-mount in situ hybridization using albino Xenopus embryos over a range of developmental stages to determine its spatial and temporal expression pattern. Using a $1.2 \mathrm{~kb}$ antisense 
Figure 4. Expression of a constitutively active $\mathrm{xCN}$ construct leads to short neurites in the absence of $\mathrm{Ca}^{2+} . A$, Myctagged CA-xCN A cRNA was coinjected into one cell of a two-cell stage embryo with mouse CN B cRNA to enhance enzymatic activity and a fluorescent lineage tracer (FITC-dextran) to identify CA$\mathrm{xCN}$-expressing cells. Nonfluorescent neurons are internal controls. Arrowheads indicate growth cones. Inset shows a myclabeled neuron at $1 \mathrm{~d}$ in culture is shown. Neurons were grown $\pm \mathrm{Ca}^{2+}$. Scale bars, $25 \mu \mathrm{m}$. $B$, Neurite extension is significantly inhibited in neurons expressing CA-xCN in the absence of external $\mathrm{Ca}^{2+}$ $(p<0.01)$. Neurons expressing CA-xCN grown in the presence of $\mathrm{Ca}^{2+}$ have neurite lengths similar to those of controls. Data are mean $\pm \operatorname{SEM}(n \geq 100)$.

\section{A}

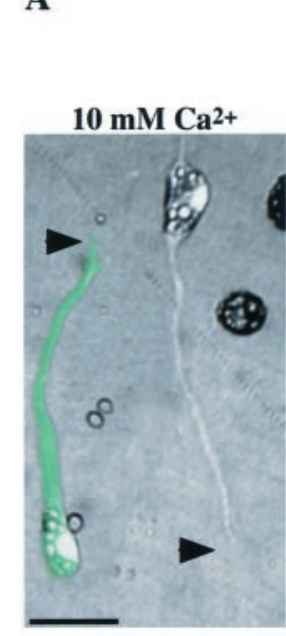

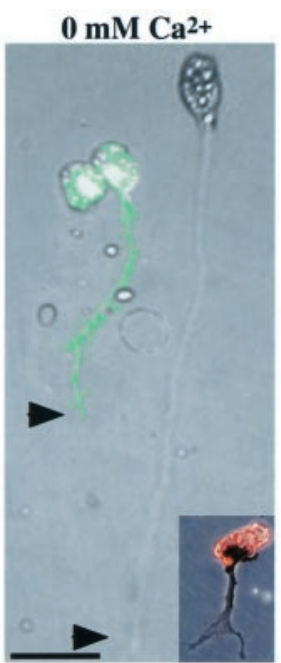
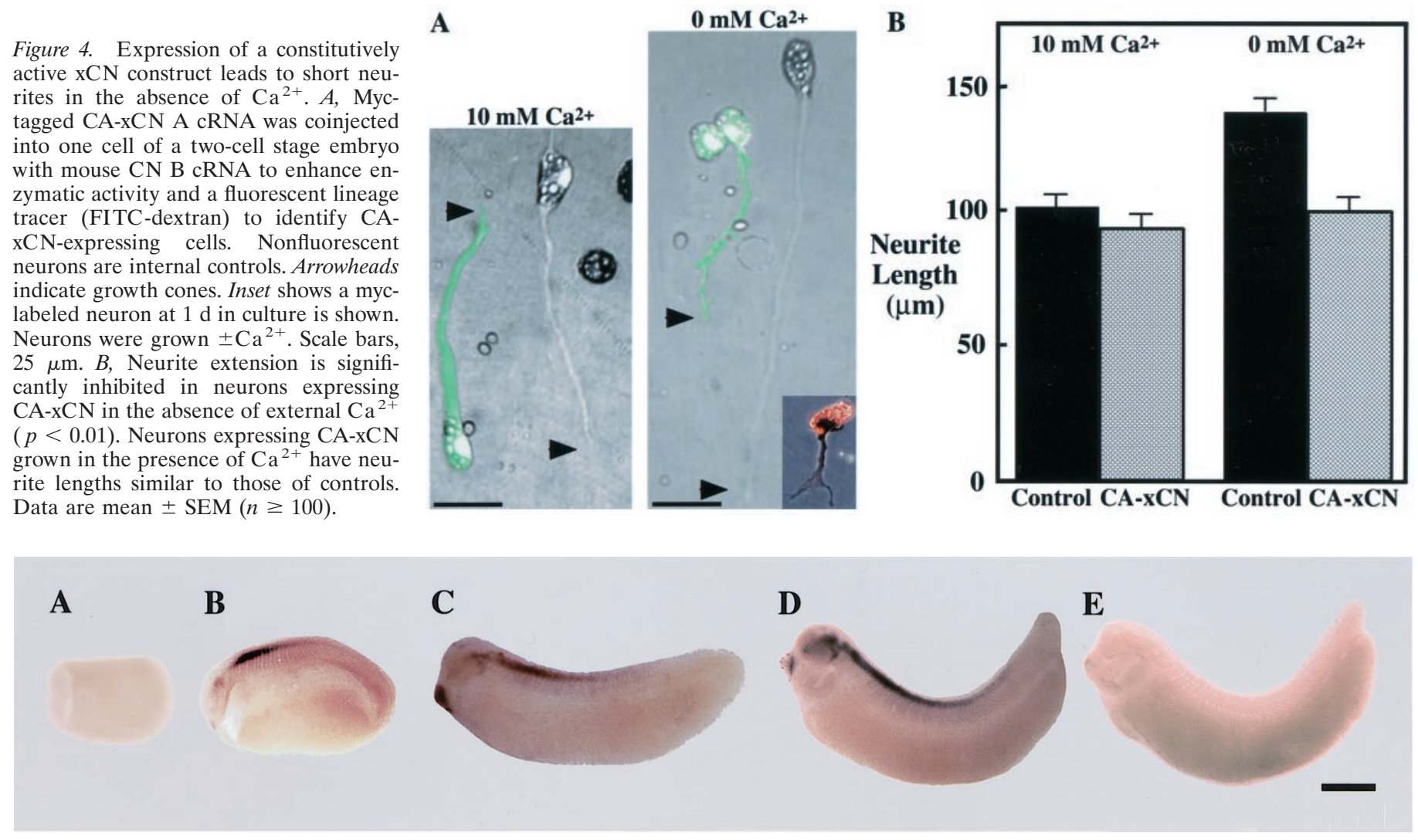

Figure 5. Developmental expression of Xenopus calcineurin transcripts is visualized by in situ hybridization of whole-mount albino Xenopus embryos with an $\mathrm{xCN}$-specific antisense probe. $A, \mathrm{xCN}$ mRNA is not detected at the neural plate stage (stage 15). $B$, Message is first observed at the neural tube stage in the presumptive brain (stage 22). $C$, Transcripts are upregulated in the brain and spinal cord by the early tailbud stage (stage 26). $D$, Expression increases posteriorly as development progresses to the late tailbud stage (stage 32). E, A control tailbud stage embryo hybridized with xCN-specific sense probe does not reveal staining, indicating specificity of the antisense. For all embryos anterior is to the left, and dorsal is $u p$. Scale bar, $500 \mu \mathrm{m}$.

fragment of the $3^{\prime}$ portion of the gene, we first detected $\mathrm{xCN}$ at the neural tube stage in the presumptive brain (Fig. 5). Transcripts are upregulated in the brain and spinal cord as development continues to tailbud stages, increasing from anterior to posterior. The expression pattern of $\mathrm{xCN}$ in vivo coincides with the $\mathrm{Ca}^{2+}$-sensitive period of neurite extension observed in vitro and in situ, placing $\mathrm{xCN}$ in the correct place and at the right time to be involved in the signal transduction pathway through which $\mathrm{Ca}^{2+}$ waves control neurite extension.

\section{Calcineurin lies downstream of $\mathrm{Ca}^{2+}$ waves}

To determine whether $\mathrm{CN}$ regulates the production of waves, we measured the frequencies of $\mathrm{Ca}^{2+}$ waves in growth cones during both inhibition and activation of $\mathrm{CN}$. Using the $\mathrm{Ca}^{2+}$ indicator dye Fluo 3 to measure changes in intracellular $\mathrm{Ca}^{2+}$, we imaged growth cones for $30 \mathrm{~min}$ between 12 and $24 \mathrm{hr}$ in culture (Fig. $6 A$ ). In the presence of $\mathrm{CsA}$ and DM at concentrations sufficient to increase neurite growth rates, spontaneous $\mathrm{Ca}^{2+}$ wave frequencies are not different from controls (Fig. 6B). Similarly, in neurons expressing CA-xCN identified by coexpression of fura2-dextran, $\mathrm{Ca}^{2+}$ wave frequencies are not different from controls. Neither the pharmacological blockers nor the constitutively active construct affect the $\mathrm{Ca}^{2+}$ wave amplitude, duration, or time integral (data not shown). Because manipulating $\mathrm{CN}$ activity had no effect on $\mathrm{Ca}^{2+}$ wave frequency, we conclude that $\mathrm{CN}$ acts downstream of $\mathrm{Ca}^{2+}$ waves in controlling neurite extension.

\section{Calcineurin does not regulate developmental expression of GABA}

$\mathrm{Ca}^{2+}$ spikes have been shown to control GABA synthesis by regulating levels of transcripts of a gene encoding the synthetic enzyme glutamic acid decarboxylase (S. D. Watt, X. Gu, R. D. Smith, and N. C. Spitzer, unpublished results). Since CN has been shown to be involved in a variety of transcriptional control pathways, including those involved in cardiac development and disease (de la Pompa et al., 1998; Molkentin et al., 1998), the immune response (O'Keefe et al., 1992; Luo et al., 1996; Shibasaki et al., 1996; Beals et al., 1997; Chow et al., 1997), and neurotransmitter release (Wang and Kelly, 1997), $\mathrm{Ca}^{2+}$ spikes could also activate $\mathrm{CN}$ to control the expression of GABA. When neurons are grown in the absence of extracellular $\mathrm{Ca}^{2+}$, spikes are abolished, and the incidence of GABA immunoreactivity drops to $10 \%$, significantly lower than the $40 \%$ of neurons that are immunoreactive in the presence of external $\mathrm{Ca}^{2+}$. To investigate whether $\mathrm{CN}$ is involved in the $\mathrm{Ca}^{2+}$-dependent expression of GABA, we examined the extent of GABA immunoreactivity in the presence of pharmacological inhibitors of $\mathrm{CN}$ or the expression of myc-tagged CA-xCN. Neither application of CsA or DM nor expression of CA-xCN affected GABA immunoreactivity in the presence and absence of $\mathrm{Ca}^{2+}$ (Fig. 6C), showing that $\mathrm{CN}$ activity is not involved in the regulation of GABA synthesis by $\mathrm{Ca}^{2+}$ spikes. 
A
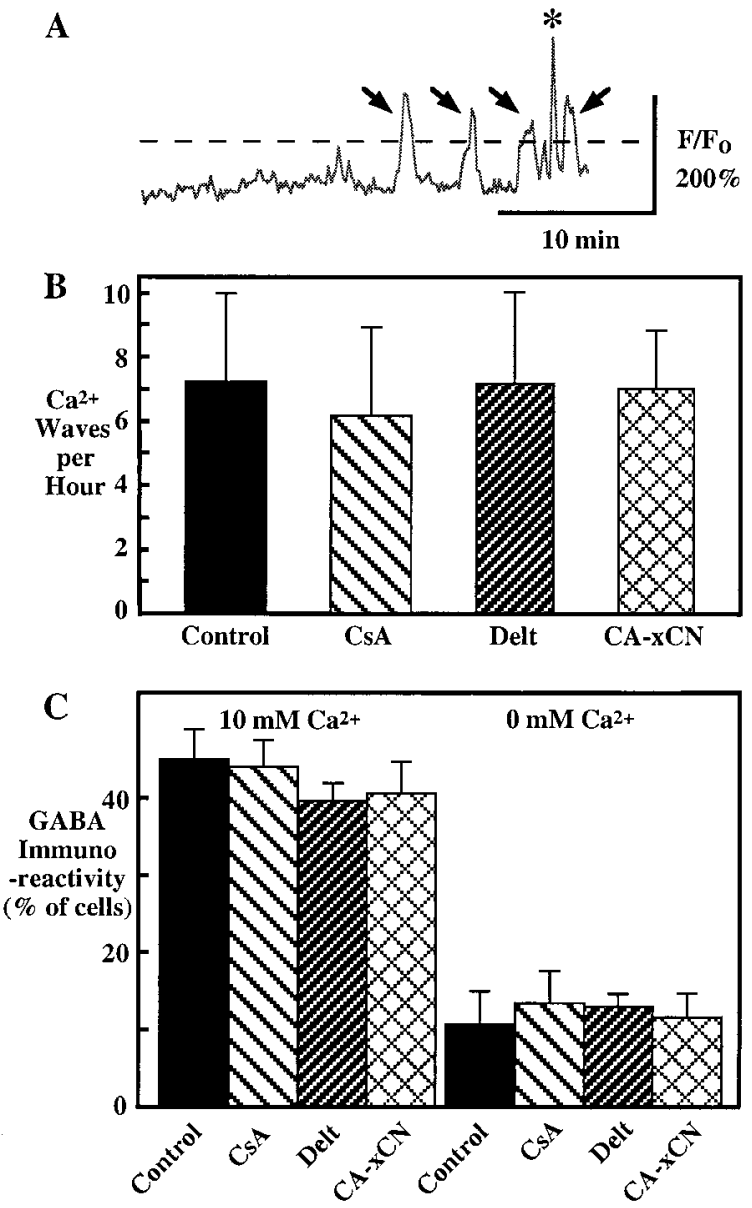

Figure 6. $\mathrm{Ca}^{2+}$ wave frequency and $\mathrm{Ca}^{2+}$-dependent expression of GABA are not affected by inhibition or activation of CN. A, Spontaneous $\mathrm{Ca}^{2+}$ waves are shown. Intracellular $\mathrm{Ca}^{2+}$ was monitored using the $\mathrm{Ca}^{2+}$ indicator dye Fluo 3, and images were acquired at $10 \mathrm{sec}$ intervals in the presence of $1 \mathrm{~nm} \mathrm{DM}$. Arrows indicate events scored as waves, the asterisk denotes a $\mathrm{Ca}^{2+}$ spike, and the dashed line indicates the event threshold. $B$, Inhibition of $\mathrm{CN}$ does not significantly affect the frequency of $\mathrm{Ca}^{2+}$ waves: control, $7 \pm 3 / \mathrm{hr}$; CsA $(10 \mathrm{nM}), 6 \pm 3 / \mathrm{hr}$; DM (Delt, $1 \mathrm{nM}), 7 \pm$ $3 / \mathrm{hr}$. Neurons expressing CA-xCN, indicated by the fluorescence of fura-2-dextran, generate spontaneous $\mathrm{Ca}^{2+}$ waves at normal frequencies in growth cones: control, $7 \pm 3 / \mathrm{hr}$; CA-xCN, $7 \pm 2 / \mathrm{hr}$. Neurons were imaged for $30 \mathrm{~min}$ intervals. Data are mean $\pm \operatorname{SEM}(n \geq 15)$. $C$, Neurons treated with either $10 \mathrm{nM}$ CsA or $1 \mathrm{nM}$ DM were assayed for expression of GABA with a rabbit anti-GABA polyclonal antibody. CN-inhibited neurons express the same extent of GABA immunoreactivity as controls. Reciprocal experiments with neurons expressing CA-xCN, confirmed by myc immunoreactivity, demonstrate no effect on GABA expression. Data are mean $\pm \operatorname{SEM}(n \geq 100)$.

\section{$\mathrm{Ca}^{2+}$ waves act via $\mathrm{XCN}$ to dephosphorylate GAP-43}

Given the function of $\mathrm{CN}$ in regulating axon outgrowth, we sought to identify targets of its action that are controlled by wave activity. GAP-43 is a known substrate of CN that is concentrated in growth cones (Liu and Storm, 1989; Apel and Storm, 1992), inhibiting actin filament polymerization and slowing neurite outgrowth when dephosphorylated (He et al., 1997). By the use of antibodies that recognize phosphorylated GAP-43, high levels have been associated with growing neurites, whereas collapsing growth cones contain low levels of phosphorylated GAP-43 (Dent and Meiri, 1998).

To test the hypothesis that $\mathrm{Ca}^{2+}$ waves act via $\mathrm{xCN}$ to dephos-

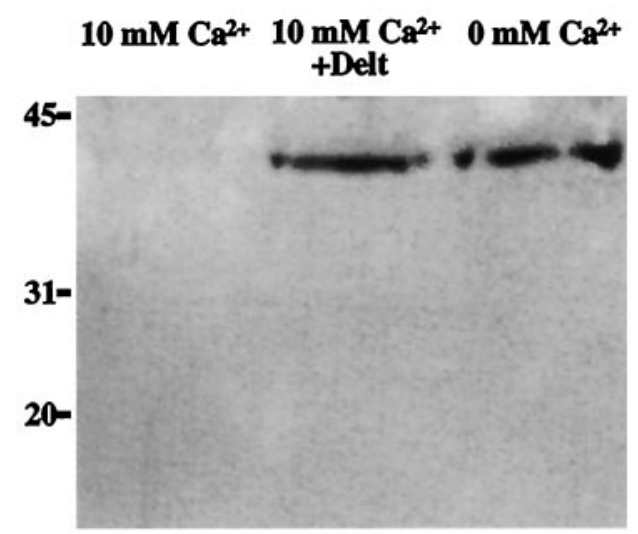

Figure 7. $\mathrm{Ca}^{2+}$ waves act via calcineurin to dephosphorylate GAP-43. A Western blot of extracts of cultured neurons grown in the presence of $\mathrm{Ca}^{2+}$ and $\mathrm{Ca}^{2+}+\mathrm{DM}$ (Delt, $\left.1 \mathrm{nM}\right)$ and in the absence of $\mathrm{Ca}^{2+}$ demonstrates that GAP-43 phosphorylation is lower in the presence of $\mathrm{Ca}^{2+}$ and that inhibiting calcineurin returns this phosphorylation to levels similar to those observed in the absence of $\mathrm{Ca}^{2+}(n=7)$.

phorylate GAP-43, we expressed rat GAP-43 in Xenopus neurons as an indicator of CN-dependent GAP-43 dephosphorylation. Using an antibody that specifically recognizes phosphorylated rat GAP-43 and does not cross-react with Xenopus GAP-43 (data not shown), we compared the extent of phosphorylated GAP-43 in the presence and absence of $\mathrm{Ca}^{2+}$ waves. Western blot analysis demonstrates that the level of phosphorylated GAP-43 increases in conditions in which $\mathrm{Ca}^{2+}$ waves are blocked and $\mathrm{xCN}$ activity is low (Fig. 7). Furthermore, suppression of $\mathrm{CN}$ activity with deltamethrin $(1 \mathrm{nM})$ in the presence of $\mathrm{Ca}^{2+}$ increases the level of phosphorylated GAP-43 to an extent similar to that achieved by removal of extracellular $\mathrm{Ca}^{2+}$. These findings suggest that GAP-43 phosphorylation is controlled by $\mathrm{Ca}^{2+}$ wave activity via $\mathrm{xCN}$.

\section{Calcineurin regulates $\mathrm{Ca}^{2+}$-dependent reorganization of the growth cone actin cytoskeleton}

Microfilaments and microtubules are crucial cytoskeletal elements for growth cone motility (Lin and Forscher, 1993; Bentley and O'Connor, 1994; Challacombe et al., 1996) and are thus likely targets of $\mathrm{Ca}^{2+}$ transients. Dephosphorylation of GAP-43 by $\mathrm{Ca}^{2+}$ waves and $\mathrm{CN}$ suggested regulation of the actin cytoskeleton. If $\mathrm{CN}$ acts on both microfilaments and microtubules in the growth cone, as implied by its immunolocalization with these cytoskeletal components (Ferreira et al., 1993), disruption or stabilization of either of these components is expected to occlude partially the effects of blocking or stimulating $\mathrm{CN}$ activity. A dose-response analysis with cytochalasin D (Cyto D), which destabilizes actin filaments, identifies a critical concentration (50 $\mathrm{nM})$ that does not lead to neurites that are shorter than those in the presence of $\mathrm{Ca}^{2+}$ (Fig. $8 A, B ; p<0.01$ ) or in the absence of $\mathrm{Ca}^{2+}$ for neurons expressing CA-xCN (Fig. $8 A$ ). However, in the presence of Cyto $\mathrm{D}$, neurites grown in the absence of $\mathrm{Ca}^{2+}$ are as short as those observed in the presence of $\mathrm{Ca}^{2+}$ waves, suggesting that waves act to destabilize filamentous actin (Fig. $8 A ; p<0.01)$. As expected, Cyto $\mathrm{D}$ also overrides the growthpromoting effect of inhibiting $\mathrm{CN}$ by $\mathrm{CsA}$ in the presence of $\mathrm{Ca}^{2+}$ and results in shortened neurite lengths. These results suggest that the enhancement of neurite outgrowth produced in the absence of waves or by suppression of $\mathrm{CN}$ is caused by increased dynamic assembly of actin filaments. Because the ef- 


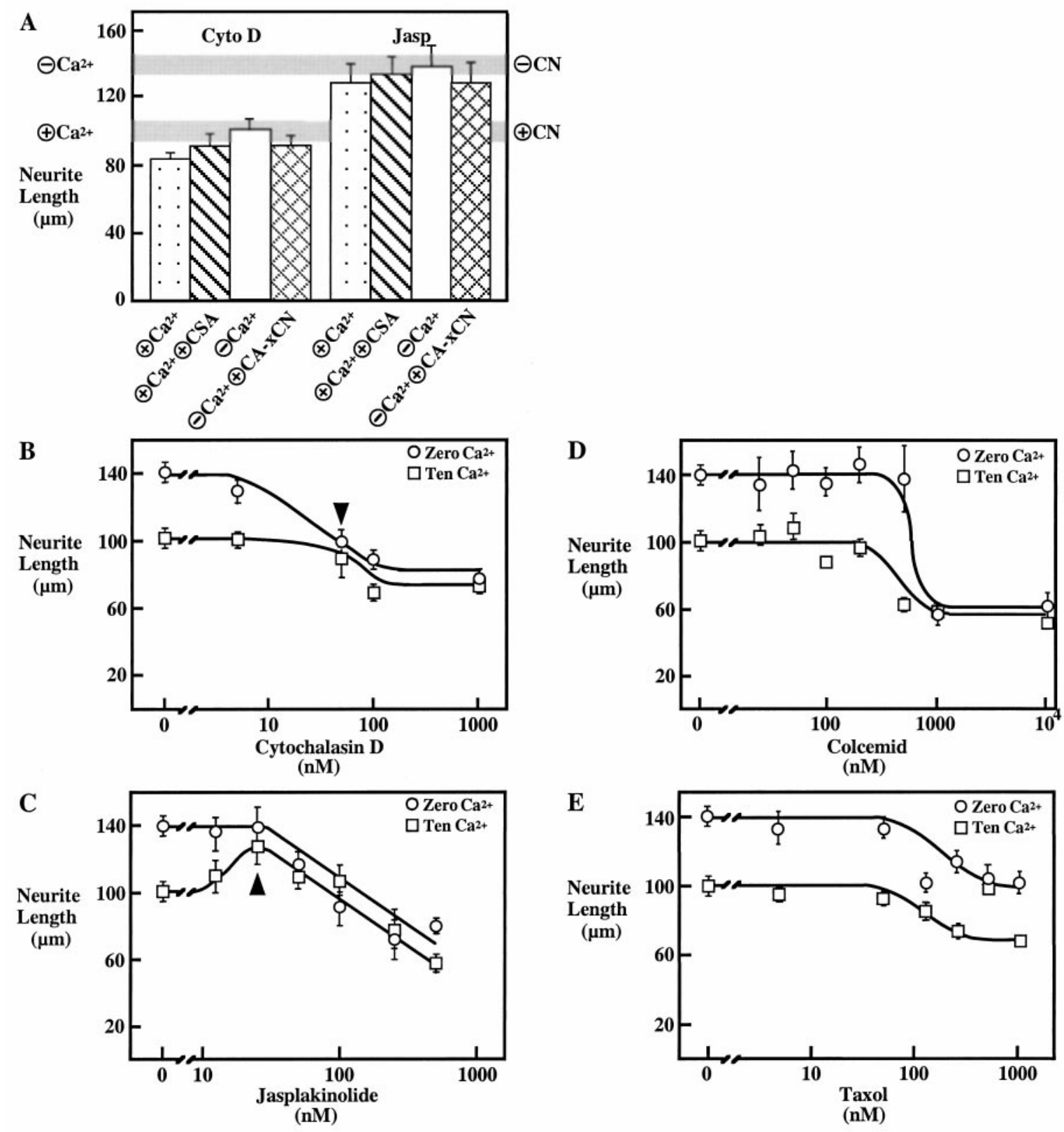

Figure 8. Disruption or stabilization of actin mimics the effects of activation or inhibition of CN. A, Shaded horizontal bars indicate neurite lengths in the presence of $\mathrm{Ca}^{2+}$ and CN activity and in their absence (see Fig. 1). Disruption of actin with Cyto D (50 nM) results in shorter neurites in the absence of CN activity, whereas stabilization of actin with Jasp $(25 \mathrm{~nm})$ generates longer neurites in the presence of CN activity. See text for further details. $B, C$, Dose-response analyses reveal the concentrations of Cyto D and Jasp (arrowheads) that mimic the effect of activating or inhibiting CN on neurite outgrowth. Disruption of actin filaments with Cyto D $(50 \mathrm{nM} ; B)$ inhibits outgrowth in the absence of $\mathrm{Ca}^{2+}$ but not in its presence, whereas Jasp $(25 \mathrm{~nm} ; C)$ increases neurite lengths in its presence of $\mathrm{Ca}^{2+}$ but not in its absence. $D, E$, Dose-response analyses demonstrate that destabilization or stabilization of microtubules with colcemide $(D)$ or taxol $(E)$ results in a $\mathrm{Ca}^{2+}$-independent inhibition of neurite outgrowth. Data are mean \pm SEM $(n \geq 30)$. CSA, CsA.

fects of $\mathrm{Ca}^{2+}$ waves and $\mathrm{CN}$ activity and actin destabilization are not additive, $\mathrm{CN}$ seems to act directly or indirectly on actin to control neurite extension.

In complementary experiments, stabilization of actin filaments with jasplakinolide (Jasp) (25 nM) (Bubb et al., 1994) in the presence of $\mathrm{Ca}^{2+}$ waves and $\mathrm{CN}$ activity results in neurite lengths similar to those seen in the absence of waves (Fig. $8 A ; p<0.01$ ). At higher concentrations of Jasp $(>50 \mathrm{nM})$, neurite growth is inhibited (Fig. $8 C$ ), probably because of overstabilization of actin filaments. Jasp does not promote additional elongation of neu- rites in the absence of $\mathrm{Ca}^{2+}$ waves or when $\mathrm{CN}$ activity is blocked with $\mathrm{CsA}$ in the presence of $\mathrm{Ca}^{2+}$. Jasp also negates the growthinhibiting effects of $\mathrm{CA}-\mathrm{xCN}$ in the absence of $\mathrm{Ca}^{2+}$ and leads to longer neurites. These results demonstrate that increased stabilization of actin promotes neurite growth in a manner similar to that seen in the absence of $\mathrm{Ca}^{2+}$ waves and $\mathrm{CN}$ activity and suggest that actin stability is correlated with neurite extension in a $\mathrm{Ca}^{2+}$ - and $\mathrm{CN}$-dependent manner.

To ascertain the role of microtubules in $\mathrm{Ca}^{2+}$ - and $\mathrm{CN}$ dependent neurite growth, we tested the effects of microtubule- 
destabilizing (colcemide) and -stabilizing (taxol) agents on neurite lengths in the presence and absence of $\mathrm{Ca}^{2+}$ and $\mathrm{CN}$ activity (Fig. 8D,E). Neurite lengths are inhibited to a similar extent in the presence or absence of $\mathrm{Ca}^{2+}$ by colcemide $(10 \mu \mathrm{M} ; 51 \%$, $\left.+\mathrm{Ca}^{2+} ; 47 \%,-\mathrm{Ca}^{2+} ; n>30\right)$ and taxol $\left(1 \mu \mathrm{M} ; 75 \%,+\mathrm{Ca}^{2+}\right.$; $\left.77 \%,-\mathrm{Ca}^{2+} ; n>30\right)$. These compounds do not appear to suppress production of $\mathrm{Ca}^{2+}$ waves, because they do not stimulate greater neurite lengths in the presence of $\mathrm{Ca}^{2+}$ at any concentration tested. The absence of a $\mathrm{Ca}^{2+}$-dependent effect of microtubule stabilization or disruption on neurite elongation suggests that this cytoskeletal component is not involved in the pathway regulated by $\mathrm{Ca}^{2+}$ waves. This result is consistent with regulation of the advance of microtubules in growth cones by actin filaments (Lin and Forscher, 1995; Letourneau, 1996), obviating a requirement for independent regulation by $\mathrm{Ca}^{2+}$ and CN activity.

\section{DISCUSSION}

\section{Calcineurin decodes $\mathrm{Ca}^{2+}$ waves to control neurite extension}

We report that $\mathrm{CN}$ is required for regulation of neurite outgrowth by spontaneous $\mathrm{Ca}^{2+}$ waves in cultured Xenopus spinal neurons. In the presence of extracellular $\mathrm{Ca}^{2+}$, enabling production of spontaneous waves, suppression of $\mathrm{CN}$ activity either pharmacologically or with an inhibitory peptide or protein results in longer neurites similar to those of neurons grown in the absence of waves. Slowing of neurite outgrowth by imposed $\mathrm{Ca}^{2+}$ transients is suppressed by CsA, further supporting the conclusion that the effect of spontaneous $\mathrm{Ca}^{2+}$ waves is mediated via $\mathrm{CN}$. Conversely, when a constitutively active construct (CA-xCN) is expressed in neurons not generating $\mathrm{Ca}^{2+}$ waves, neurites are shorter and similar in length to those generating $\mathrm{Ca}^{2+}$ waves. This observation in conjunction with the absence of inhibition in the presence of extracellular $\mathrm{Ca}^{2+}$ argues that there are few if any spurious effects of its expression. However we cannot exclude the possibility that $\mathrm{CA}-\mathrm{xCN}$ expression has effects before neurite extension. Previous pharmacological studies implicate $\mathrm{CN}$ in axonal regeneration (Lyons et al., 1994; Chang et al., 1995), but more recent reports suggest that immunophilins are the principal agents in some cases (Gold, 1997; Snyder et al., 1998). Our observations of the effect of $\mathrm{DM}$ and the $\mathrm{CN}$ autoinhibitory peptide, which block $\mathrm{CN}$ by mechanisms that do not involve immunophilins (Enan and Matsumura, 1992; Sagoo et al., 1996), and the absence of an effect of Rap, which binds to immunophilins but does not block CN (Liu et al., 1991), support a role for $\mathrm{CN}$ in $\mathrm{Ca}^{2+}$-dependent neurite extension. Our results suggest that $\mathrm{Ca}^{2+}$-dependent regulation of neurite length is not attributable to other serine-threonine phosphatases. Because $\mathrm{xCN}$ is expressed in the spinal cord of the developing embryo during the time when axon outgrowth is occurring (Gomez and Spitzer, 1999), it is likely to regulate neurite extension and pathfinding in vivo. $\mathrm{CN}$ activity does not affect the natural frequency of $\mathrm{Ca}^{2+}$ waves in growth cones, placing $\mathrm{CN}$ downstream of waves in the $\mathrm{Ca}^{2+}$-dependent cascade that controls neurite elongation. We also demonstrate that $\mathrm{CN}$ is not the only $\mathrm{Ca}^{2+}$-transient sensor in Xenopus neurons, because inhibition of endogenous $\mathrm{xCN}$ and expression of CA-xCN do not affect a second $\mathrm{Ca}^{2+}$-dependent pathway by which spontaneous $\mathrm{Ca}^{2+}$ spikes control expression of GABA.

Wave activity controls GAP-43 phosphorylation levels via $\mathrm{CN}$, suggesting that $\mathrm{xCN}$ acts via GAP-43 to regulate cytoskeletal actin structure and neurite length. Removing the contribution of the actin network to neurite extension with Cyto D or Jasp reveals the effect of $\mathrm{Ca}^{2+}$ on microtubules in neurite outgrowth and shows that at high concentrations of Cyto $\mathrm{D}$ and Jasp there is no difference in neurite outgrowth $\pm \mathrm{Ca}^{2+}$. Thus $\mathrm{Ca}^{2+}$ elevations seem to have little effect on microtubules. Conversely, when the contribution of microtubule dynamics to neurite outgrowth is removed by colcemide or taxol, the $\mathrm{Ca}^{2+}$-dependent effect on actin is apparent. Stabilization of microtubules with taxol does not affect $\mathrm{Ca}^{2+}$-dependent regulation of neurite length. However, when microtubules are destabilized by colcemide, neurites are inhibited similarly $\pm \mathrm{Ca}^{2+}$, presumably because the actin network is dependent on a microtubular scaffold. These experiments support the hypothesis that $\mathrm{Ca}^{2+}$ transients that act to destabilize the actin network have substantially less effect on microtubules. The results are consistent with observations that $\mathrm{Ca}^{2+}$ suppresses growth cone motility in chick dorsal root ganglion neurons (Lankford and Letourneau, 1989) and that elevation of $\mathrm{Ca}^{2+}$ is mimicked by low doses of cytochalasins (Lankford and Letourneau, 1991). The activity of CN seems to be both necessary and sufficient to suppress the organization of the growth cone actin cytoskeleton associated with rapid neurite outgrowth. Disruption or stabilization of the actin cytoskeleton occludes the effects of altering the activity of $\mathrm{CN}$.

\section{A model for $\mathrm{CN}$ regulation of neurite length}

$\mathrm{CN}$ is an abundant $\mathrm{Ca}^{2+}$ - and calmodulin-dependent protein phosphatase, comprising $\sim 1 \%$ of the total protein in brain (Klee et al., 1988). Its widespread expression underscores the many roles it plays in a variety of signal transduction cascades (Yakel, 1997), and it has been implicated in transcriptional control of numerous signaling pathways. However the effects of local inactivation of CN (Chang et al., 1995) and the ability of isolated growth cones to respond to $\mathrm{Ca}^{2+}$ elevations (Rehder and Cheng, 1998) both make it unlikely that activation of $\mathrm{CN}$ via $\mathrm{Ca}^{2+}$ influx

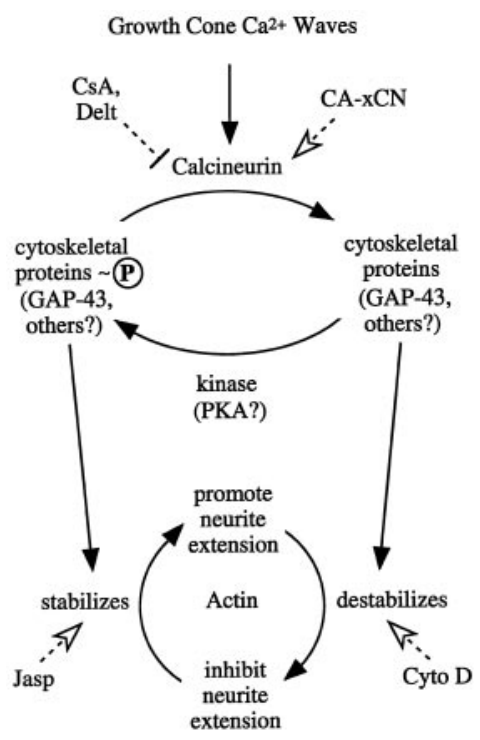

Figure 9. Model of the signal transduction cascade by which $\mathrm{Ca}^{2+}$ waves act via $\mathrm{CN}$ to regulate neurite extension. $\mathrm{Ca}^{2+}$ waves activate $\mathrm{CN}$, shifting cytoskeletal-regulating proteins to a dephosphorylated state, destabilizing actin filaments, and inhibiting neurite elongation. $\mathrm{CN}$ is not activated in the absence of $\mathrm{Ca}^{2+}$ waves, shifting cytoskeletal-regulating proteins to a phosphorylated state, stabilizing actin filaments, and promoting neurite outgrowth. Activating or inhibiting this cascade at different points increases or decreases neurite extension. Delt, DM. 
influences local cytoskeletal reorganization via a transcriptional mechanism. Activation of $\mathrm{CN}$ by $\mathrm{Ca}^{2+}$ transients promotes migration in neutrophils (Lawson and Maxfield, 1995), in contrast to the inhibition of neurite outgrowth reported here. Thus a single enzyme can have different effects depending on other components of the signal transduction cascade in which it functions.

Regulation of neurite extension by the phosphorylation state of cytoskeletal components in the growth cone raises the question of the identity of the reciprocal kinase that acts in concert with $\mathrm{CN}$ to promote the outgrowth of neurites. $\mathrm{CN}$ is associated with PKA and PKC via AKAP79, a common anchoring protein in neurons, which suggests that these two kinases act on common substrates to control their phosphorylation state (Coghlan et al., 1995; Klauck et al., 1996). PKC does not seem to play a role in regulation of neurite extension in Xenopus spinal neurons, because suppression and stimulation of its activity with different concentrations of phorbol 12-myristate 13-acetate (PMA) have no effect on neurite outgrowth ( $\mathrm{Gu}$ and Spitzer, 1995). These findings, together with preliminary evidence that neurite lengths are longer when Xenopus spinal neurons are grown in the presence of 8-bromo-cAMP (Y. Gorbunora and N. C. Spitzer, unpublished observations), make PKA an attractive candidate in a reciprocal model of growth cone phosphorylation levels (Fig. 9). Furthermore, PKA has been shown to phosphorylate GAP-43 in cultures of rat striatum (Schmidt et al., 1998), and regulation of neurite outgrowth by $\mathrm{CN}$ and PKA has been described for cultured chick dorsal root ganglion neurons (Letourneau, 1996). Additionally this model provides a mechanism that allows independent stimulation and inhibition of neurite outgrowth.

Although $\mathrm{CN}$ activity inhibits neurite elongation by its effect on the actin cytoskeleton, many other components are involved in promoting $\mathrm{Ca}^{2+}$-independent neurite outgrowth. For example, microtubule-associated protein (MAP)-1B regulates microtubule bundling, cross-linking of microtubule and actin filaments, and axon extension in a phosphorylation-dependent manner (Gordon-Weeks, 1993; Avila et al., 1994; Ulloa et al., 1994). A substantial increase in MAP-1B phosphorylation occurs in differentiating neurons (Diaz-Nido et al., 1990) and may be required to assemble a stable microtubule scaffold (Denoulet et al., 1989; Diaz-Nido et al., 1990). MAP-1B is phosphorylated by casein kinase or proline-directed protein kinases (Diaz-Nido et al., 1990; Avila et al., 1994), but the phosphatase that dephosphorylates it is presently unknown. Thus multiple mechanisms converge to regulate axon extension in embryonic neurons.

\section{REFERENCES}

Altschul SF, Madden TL, Schäffer AA, Zhang J, Zhang Z, Miller W, Lipman DJ (1997) Gapped BLAST and PSI-BLAST: a new generation of protein database search programs. Nucleic Acids Res 25:3389-3402.

Apel ED, Storm DR (1992) Functional domains of neuromodulin (GAP43). Perspect Dev Neurobiol 1:3-11.

Avila J, Ulloa L, Gonzalez J, Moreno F, Diaz-Nido J (1994) Phosphorylation of microtubule-associated proteins by protein kinase CK2 in neuritogenesis. Cell Mol Biol Res 40:573-579.

Beals CR, Clipstone NA, Ho SN, Crabtree GR (1997) Nuclear localization of NF-ATc by a calcineurin-dependent, cyclosporin-sensitive intramolecular interaction. Genes Dev 11:824-834.

Bentley D, O'Connor TP (1994) Cytoskeletal events in growth cone steering. Curr Opin Neurobiol 4:43-48.

Berridge MJ, Rapp PE (1979) A comparative survey of the function, mechanism and control of cellular oscillators. J Exp Biol 81:217-279.

Bixby JL, Spitzer NC (1984) Early differentiation of vertebrate spinal neurons in the absence of voltage-dependent $\mathrm{Ca}^{++}$and $\mathrm{Na}^{+}$influx. Dev Biol 106:89-96.
Bubb MR, Senderowicz AM, Sausville EA, Duncan KL, Korn ED (1994) Jasplakinolide, a cytotoxic natural product, induces actin polymerization and competitively inhibits the binding of phalloidin to F-actin. J Biol Chem 269:14869-14871.

Burger C, Ribera AB (1996) Xenopus spinal neurons express Kv2 potassium channel transcripts during embryonic development. J Neurosci 16:1412-1421.

Challacombe JF, Snow DM, Letourneau PC (1996) Actin filament bundles are required for microtubule reorientation during growth cone turning to avoid an inhibitory guidance cue. J Cell Sci 109:2031-2040.

Chang HY, Takei K, Sydor AM, Born T, Rusnak F, Jay DG (1995) Asymmetric retraction of growth cone filopodia following focal inactivation of calcineurin. Nature 376:686-690.

Chow CW, Rincon M, Cavanagh J, Dickens M, Davis RJ (1997) Nuclear accumulation of NFAT4 opposed by the JNK signal transduction pathway. Science 278:1638-1641.

Clipstone NA, Fiorentino DF, Crabtree GR (1994) Molecular analysis of the interaction of calcineurin with drug-immunophilin complexes. J Biol Chem 269:26431-26437.

Coghlan VM, Perrino BA, Howard M, Langeberg LK, Hicks JB, Gallatin WM, Scott JD (1995) Association of protein kinase A and protein phosphatase 2B with a common anchoring protein. Science 267:108-111.

Cohan CS, Kater SB (1986) Suppression of neurite elongation and growth cone motility by electrical activity. Science 232:1638-1640.

Deisseroth K, Bito H, Schulman H, Tsien RW (1995) Synaptic plasticity: a molecular mechanism for metaplasticity. Curr Biol 12:1334-1338.

Deisseroth K, Heist EK, Tsien RW (1998) Translocation of calmodulin to the nucleus supports CREB phosphorylation in hippocampal neurons. Nature 392:198-202.

De Koninck P, Schulman H (1998) Sensitivity of CaM kinase II to the frequency of $\mathrm{Ca}^{2+}$ oscillations. Science 279:227-230.

de la Pompa JL, Timmerman LA, Takimoto H, Yoshida H, Elia AJ, Samper E, Potter J, Wakeham A, Marengere L, Langille BL, et al. (1998) Role of the NF-ATc transcription factor in morphogenesis of cardiac valves and septum. Nature 392:182-186.

Denoulet P, Filliatreau G, de Nechaud B, Gros F, Di Giamberardino L (1989) Differential axonal transport of isotubulins in the motor axons of the rat sciatic nerve. J Cell Biol 108:965-971.

Dent EW, Meiri KF (1998) Distribution of phosphorylated GAP-43 (neuromodulin) in growth cones directly reflects growth cone behavior. J Neurobiol 35:287-299.

Diaz-Nido J, Serrano L, Hernandez MA, Avila J (1990) Phosphorylation of microtubule proteins in rat brain at different developmental stages: comparison with that found in neuronal cultures. J Neurochem 54:211-222.

Enan E, Matsumura F (1992) Specific inhibition of calcineurin by type II synthetic pyrethroid insecticides. Biochem Pharmacol 43:1777-1784.

Favre B, Turowski P, Hemmings BA (1997) Differential inhibition and posttranslational modification of protein phosphatase 1 and $2 \mathrm{~A}$ in MCF7 cells treated with calyculin-A, okadaic acid, and tautomycin. J Biol Chem 272:13856-13863.

Ferreira A, Kincaid R, Kosik KS (1993) Calcineurin is associated with the cytoskeleton of cultured neurons and has a role in the acquisition of polarity. Mol Biol Cell 4:1225-1238.

Ferreiro B, Skoglund P, Bailey A, Dorski R, Harris WA (1992) XASH1, a Xenopus homologue of Achaete-scute: a proneural gene in anterior regions of the vertebrate central nervous system. Mech Dev 40:25-36.

Fields RD, Neale EA, Nelson PG (1990) Effects of patterned electrical activity on neurite outgrowth from mouse sensory neurons. J Neurosci 10:2950-2964.

Gold BG (1997) FK506 and the role of immunophilins in nerve regeneration. Mol Neurobiol 15:285-306.

Gomez TM, Spitzer NC (1999) In vivo regulation of axon extension and pathfinding by growth cone calcium transients. Nature 397:350-355.

Gomez TM, Snow DM, Letourneau PC (1995) Characterization of spontaneous calcium transients in nerve growth cones and their effect on growth cone migration. Neuron 14:1233-1246.

Gordon-Weeks PR (1993) Organization of microtubules in axonal growth cones: a role for microtubule-associated protein MAP $1 \mathrm{~B}$. J Neurocytol 22:717-725.

Gu X, Spitzer NC (1995) Distinct aspects of neuronal differentiation encoded by frequency of spontaneous $\mathrm{Ca}^{++}$transients. Nature 375:784-787. 
Gu X, Olson EC, Spitzer NC (1994) Spontaneous neuronal calcium spikes and waves during early differentiation. J Neurosci 14:6325-6335.

Guerini D, Krinks MH, Sikela JM, Hahn WE, Klee CB (1989) Isolation and sequence of a cDNA clone for human calcineurin $\mathrm{B}$, the $\mathrm{Ca}^{2+}$ binding subunit of the $\mathrm{Ca}^{2+} /$ calmodulin-stimulated protein phosphatase. DNA 8:675-682.

Harland R (1991) In situ hybridization: an improved whole-mount method for Xenopus embryos. Methods Cell Biol 36:675-685.

Haydon PG, McCobb DP, Kater SB (1984) Serotonin selectively inhibits growth cone motility and synaptogenesis of specific identified neurons. Science 226:561-564.

He Q, Dent EW, Meiri KF (1997) Modulation of actin filament behavior by GAP-43 (neuromodulin) is dependent on the phosphorylation status of serine 41, the protein kinase C site. J Neurosci 17:3515-3524.

Hubbard MJ, Klee CB (1989) Functional domain structure of calcineurin A: mapping by limited proteolysis. Biochemistry 28:1868-1874.

Klauck TM, Faux MC, Labudda K, Langeberg LK, Jaken S, Scott JD (1996) Coordination of three signaling enzymes by AKAP79, a mammalian scaffold protein. Science 271:1589-1592.

Klee CB, Draetta GF, Hubbard MJ (1988) Calcineurin. Adv Enzymol Relat Areas Mol Biol 61:149-200.

Lankford KL, Letourneau PC (1989) Evidence that calcium may control neurite outgrowth by regulating the stability of actin filaments. J Cell Biol 109:1229-1243.

Lankford KL, Letourneau PC (1991) Roles of actin filaments and three second-messenger systems in short-term regulation of chick dorsal root ganglion neurite outgrowth. Cell Motil Cytoskeleton 20:7-29.

Lawson MA, Maxfield FR (1995) $\mathrm{Ca}^{2+}$ - and calcineurin-dependent recycling of an integrin to the front of migrating neutrophils. Nature 377:75-79.

Letourneau PC (1996) The cytoskeleton in nerve growth cone motility and axonal pathfinding. Perspect Dev Neurobiol 4:111-123.

Lin CH, Forscher P (1993) Cytoskeletal remodeling during growth cone-target interactions. J Cell Biol 121:1369-1383.

Lin CH, Forscher P (1995) Growth cone advance is inversely proportional to retrograde F-actin flow. Neuron 14:763-771.

Liu J, Farmer Jr JD, Lane WS, Friedman J, Weissman I, Schreiber SL (1991) Calcineurin is a common target of cyclophilin-cyclosporin A and FKBP-FK506 complexes. Cell 66:807-815.

Liu YC, Storm DR (1989) Dephosphorylation of neuromodulin by calcineurin. J Biol Chem 264:12800-12804.

Luo C, Burgeon E, Carew JA, McCaffrey PG, Badalian TM, Lane WS, Hogan PG, Rao A (1996) Recombinant NFAT1 (NFATp) is regulated by calcineurin in $\mathrm{T}$ cells and mediates transcription of several cytokine genes. Mol Cell Biol 16:3955-3966.

Lyons WE, George EB, Dawson TM, Steiner JP, Snyder SH (1994) Immunosuppressant FK506 promotes neurite outgrowth in cultures of PC12 cells and sensory ganglia. Proc Natl Acad Sci USA 91:3191-3195.

MacKintosh C, MacKintosh RW (1994) Inhibitors of protein kinases and phosphatases. Trends Biochem Sci 19:444-448.

Malinow R, Schulman H, Tsien RW (1989) Inhibition of postsynaptic PKC or CaMKII blocks induction but not expression of LTP. Science 245:862-866.

Mattson MP, Dou P, Kater SB (1988) Outgrowth-regulating actions of glutamate in isolated hippocampal pyramidal neurons. J Neurosci 8:2087-2100.

Meiri KF, Hammang JP, Dent EW, Baetge EE (1996) Mutagenesis of Ser41 to Ala inhibits the association of GAP-43 with the membrane skeleton of GAP-43-deficient PC12B cells: effects on cell adhesion and the composition of neurite cytoskeleton and membrane. J Neurobiol 29:213-232.

Meyer T, Stryer L (1991) Calcium spiking. Annu Rev Biophys Biophys Chem 20:153-174.

Miskin JE, Abrams CC, Goatley LC, Dixon LK (1998) A viral mechanism for inhibition of the cellular phosphatase calcineurin. Science 281:562-565.

Molkentin JD, Lu JR, Antos CL, Markham B, Richardson J, Robbins J, Grant SR, Olson EN (1998) A calcineurin-dependent transcriptional pathway for cardiac hypertrophy. Cell 93:215-228.

Nieuwkoop PD, Faber J (1967) Normal table of Xenopus laevis (Daudin): a systematic and chronological survey of the development of the fertilized egg till the end of metamorphosis, 2nd Edition. Amsterdam: North Holland.

O'Keefe SJ, Tamura J, Kincaid RL, Tocci MJ, O’Neill EA (1992) FK506- and CsA-sensitive activation of the interleukin-2 promoter by calcineurin. Nature 357:692-694.

Perrino BA, Ng LY, Soderling TR (1995) Calcium regulation of calcineurin phosphatase activity by its B subunit and calmodulin. Role of the autoinhibitory domain. J Biol Chem 270:340-346.

Rehder V, Cheng S (1998) Autonomous regulation of growth cone filopodia. J Neurobiol 34:179-192.

Ribera AB, Spitzer NC (1989) A critical period of transcription required for differentiation of the action potential of spinal neurons. Neuron 2:1055-1062.

Sagoo JK, Fruman DA, Wesselborg S, Walsh CT, Bierer B (1996) Competitive inhibition of calcineurin phosphatase activity by its autoinhibitory domain. Biochem J 320:879-884.

Schmidt U, Pilgrim C, Beyer C (1998) Differentiative effects of dopamine on striatal neurons involve stimulation of the cAMP/PKA pathway. Mol Cell Neurosci 11:9-18.

Shibasaki F, Price ER, Milan D, McKeon F (1996) Role of kinases and the phosphatase calcineurin in the nuclear shuttling of transcription factor NF-AT4. Nature 382:370-373.

Snyder SH, Lai MM, Burnett PE (1998) Immunophilins in the nervous system. Neuron 21:283-294.

Spitzer NC, Sejnowski TJ (1997) Biological information processing: bits of progress. Science 277:1060-1061.

Spitzer NC, de Baca RC, Allen KA, Holliday J (1993) Calcium dependence of differentiation of GABA immunoreactivity in spinal neurons. J Comp Neurol 337:168-175.

Tsien RW, Tsien RY (1990) Calcium channels, stores, and oscillations. Annu Rev Cell Biol 6:715-760.

Ueki K, Muramatsu T, Kincaid RL (1992) Structure and expression of two isoforms of the murine calmodulin-dependent protein phosphatase regulatory subunit (calcineurin B). Biochem Biophys Res Commun 187:537-543.

Ulloa L, Diaz-Nido J, Avila J (1994) Depletion of catalytic and regulatory subunits of protein kinase CK2 by antisense oligonucleotide treatment of neuroblastoma cells. Cell Mol Neurobiol 14:407-414.

Wang JH, Kelly PT (1997) Attenuation of paired-pulse facilitation associated with synaptic potentiation mediated by postsynaptic mechanisms. J Neurophysiol 78:2707-2716.

Yakel JL (1997) Calcineurin regulation of synaptic function: from ion channels to transmitter release and gene transcription. Trends Pharmacol Sci 18:124-134.

Zheng JQ, Felder M, Connor JA, Poo MM (1994) Turning of nerve growth cones induced by neurotransmitters. Nature 368:140-144. 